\title{
Nigerian Security Forces and the Management of Internal Conflict in the Niger Delta: Challenges of Human Security and Development
}

By

Dr Robert O. Dode ${ }^{1}$

\begin{abstract}
The Nigerian Armed Forces personnel have over the years maintained a track record of effective peace keeping campaigns in the world. The role Nigeria played in especially crises ridden Sierra Leone and Liberia can not be overemphasized. Paradoxically though, this record does not seem to be playing out in their security and crisis operations in the country. Analysts would quickly make reference to Umuechem, Odi and recently, the military bombardment of Ijaw communities in Gbaramatu Kingdom in Warri South West Council of Delta State. Some studies have shown that at the end of most of those operations, the military stay behind as "armies of occupation". This paper therefore, raises a number of questions which include: how effective and to whose benefit have measures adopted (like aerial bombardment) in the management of internal crisis by security forces in Nigeria been in recent times (1999-2011)? Is it not an indirect call for military interregnum, when democratic regimes authorize the rolling out of war machines by the military against the civilians? Are the military forces fully trained in surveillance and other non-combative skills of security maintenance? This study intends to consider a number of options available for the country to adopt and solve crisis situations with minimal collateral damage. These options include good governance, genuine national dialogue, adequate surveillance of the Niger Delta creeks, blocking of the sources of small and light weapons importation and sale of illegally bunkered crude oil into the international market.
\end{abstract}

Key Words: security, oil, conflicts, crisis management

${ }^{1}$ DEPT. OF POL. SCIENCE \& PUBLIC ADMINISTRATION, UNIVERSITY OF UYO P. O. B.OX 4262 UNIVERSITY OF UYO, UYO, NIGERIA robertdode@yahoo.com 08035455770 


\section{Introduction}

Africa and indeed a number of other continents in the world has experienced one form of cross border crisis (wars) or the other. These continents have equally experienced series of internal crisis. These crises include insurrection, civil wars and political uprisings (agitations). Galadima (2007) writing about the African condition has observed that

\section{Conflicts erupted into warfare in Central Africa,} Zaire, Burundi; and Rwanda. There was armed uprising in Northern Uganda, civil war in Sudan and border conflicts between Ethiopia and Eritrea. Somalia has remained a collapsed state inspite of attempts to resuscitate it. In Southern Africa, Lesotho witnessed an armed uprising. Angola was also in turmoil. In West Africa, Liberia was almost a collapsed state, even as rebels embattled Sierra Leone and Guinea-Bissau. While Cote d' Ivoire experiences armed rebellion, Sudan is encountering bumanitarian catastrophe arising from a bitter intrastate conflict, almost on a genocidal proportion (p.295).

Where some of these conflicts have ceased or truce brokered (cease-fire) among the contending forces, it is always expedient for the United Nations organization (UNO) or some regional bodies to ensure the maintenance of peace and security; to avoid another period of complete breakdown of law and order. It is this necessity that leads to the setting up of peace-keeping missions around the world. In such locations, military personnel and police officers and men from different parts of the world are assembled to help ensure some level of stability, after a long period of conflict.

Records have it that Africa accounts for over 80 percent of existing peacemissions UN deployed world wide. The eight missions in Africa are said to be supported by roughly 49,000 UN peace keepers (UNDPKO, http://www.un.org/Dept/dpko).

Nigerian security personnel have at one point or the other, participated creditably in some of these peace-keeping missions over the years. The Nigerian armed forces and police personnel have, from available records, maintained a track record of effective peace-keeping campaigns in the globe. This record of success has earned for the nation, a number of international recognitions and 
commendations. The officers concerned have equally won honours and got decorated with medals of honour. The government and people of Sierra Leone and Liberia in particular, at regular intervals, express gratitude to the government and people of Nigeria. This is with regard to the noble role played by Nigerian armed forces in restoring peace and sanity to those countries.

With such high profile rating in the way they conduct themselves when on international peace-keeping operations, it was expected that the Nigerian armed forces would display the same record while on national (internal) peace-keeping operations. A number of factors however, tend to expose some problems inherent in the way they have handled internal crisis flash-points, to which they have been drafted to maintain peace. A number of analysts of these internal operations have pointed to the problem of high handedness and insensitivity to the nature and characteristics of civilian dominated areas, howbeit, with an admixture of rebel elements. The dust usually left behind crisis scenes in Nigeria by military personnel (drafted to such areas) leaves much to be desire, hence, the need for an analysis of this nature. Examples of places where military forces have left behind such woes are Umuechem, Odi and Gbaramatu.

The questions to be addressed in the body of this paper include; how effective and to whose benefit have measures adopted so far by the Nigerian armed forces in the management of internal conflicts been in recent times? Is it not an indirect call for military interregnum, when democratic regimes authorize the rolling out of war machines by the military against largely defenseless civilians? Are Nigerian armed forces personnel adequately trained in surveillance and other non-combative skills of security maintenance?

This work will proceed with the adoption of the Systemic theories as its theoretical frame of reference. Available literature on this school of thought shows a thesis that revolves around a major argument, which in the words of Faleti (2007), "provide a socio-structural explanation for the mergence of violent social conflicts" (p.53). The major focus of this theory therefore, is that it tries to identify the reason(s) for social conflict in a particular environment to the social context within which it occurs. Thus, for one to understand the reason for the upsurge of a particular conflict, one has to look closely within the primary environment within which it occurred.

The systemic theory to a large extent tends to put forward, certain thesis advanced by the scholars who belong to the environmental-determinism school of thought. The latter argue, inter alia that the environment, to a large extent determines the behavior of people within a particular area. Thus, Falati (2007), (quoting Johnson, 1960), observes, with regard to political violence that, "any analytical penetration of the behavior characterized as 'purposive political 
violence' must utilize as its tool a conception of the context in which it occurs" (p.53).

Part of the position held by this paradigm is that is that the systemic factors that lead to changes in peoples' material comfort include environmental degradation that reduces access to sources of livelihood, uncontrolled population growth, resource scarcity, widespread poverty in the midst of plenty, the domination and marginalization of minority groups by those in the majority, and ethnicity. It is within these examples of systemic causes of conflict that this paper attempts to locate the major causes of the Niger Delta crisis, the ensuing military operations and practical solutions to the identified problems, different from direct military invasion.

The Niger Delta of Nigeria has for some decades recorded widespread agitation for better deal from the Federal Government. For about a decade now, however, these agitations have assumed a violent dimension, with heavy casualties recorded in the Federal and militant camps. That region has become the highest flash-point of conflict between groups and recently, militants and federal troops posted to secure facilities in that part of the country. The Niger Delta problem, data has shown, revolve around the factor of environmental degradation, which the Systemic theory adopted above has rightly captured. This problem has to a large extent, reduced the peoples' access to sources of livelihood and led to resource scarcity, even in the midst of plenty. Environmental degradation has indeed drummed up the cry against marginalization and domination by those in the majority. It has thus fanned further, the embers of ethnicity, with this giving way to the present state of insecurity in the Niger Delta states.

The Federal Government of Nigeria has largely reacted to the above mentioned agitations through the use of military force. The major questions are, how effective and permanent has this military option to the conflict situation in the Niger Delta been? How have the officers and men of the armed forces posted to maintain peace in those areas carried on with their official assignment, bearing in mind the fact that these were fellow Nigerians.

\section{Nigerian Security Forces/Joint Task Force}

By the Nigerian security forces in this work, we mean a conglomeration of security personnel whose primary assignment (constitutionally determined), is to protect the state from external aggression and internal insurrection, while maintaining peace and order. It is from the perspective of the latter that this paper launches out to investigate the role so far played by security forces in reducing, stopping or escalating conflicts in the Niger delta. These security forces include the Nigerian Army, Air Force, and Navy, police Force, Security agencies and Civil Defense Corps among others. 
Nnoli (2006) has categorized the expected task(s) of the military in a contemporary democratic state into two. According to him:

One is to do nothing that would detract from the establishment and consolidation of the system. In the performance of the first task emphasis is placed on ensuring that the military never ever intervenes in the politics of any African state. This is because, as Claude Ake has observed, democracy and the military are in a dialectical opposition. The military is the antithesis of democracy with regard to its forms, values, purpose and structure (p.185).

This truism constitutes part of a question raised in this works which state: is it not an indirect call for military interregnum, when democratic regimes authorize the rolling out of war machines by the military against the civilians?

\section{Crisis Management}

A brief on the concepts, crisis and conflict would make for a better understanding of conflict management theories and processes.

Conflict has been variously defined as an environment characterized by incompatibility of dates or events. It equally refers to opposition between two simultaneous but incompatible feelings. To Coser (1956), conflict simply refers to "a struggle over values and claims to scarce status, power and resources in which the aims of the opponents are to neutralize, injure or eliminate their rivals" (p.8). thus, conflicts seem to arise wherever there is the pursuit of divergent interests, goals and aspirations by which individuals and, or groups in defined social and physical environments (see Otite and Albert, 1999). It is this sense of "incompatibility" of events or ownership over an object or environment that leads to crisis (if not nipped in the bud).

Crisis on the other hand is defined as "a crucial stage or turning point in the course of something" (http:jDictionary-mobile.com).

On a general note, conflicts can be violent or non-violent in nature. The bottom line is that there is in existence, some kind of strong disagreement (incompatibility) of views over a particular phenomenon. In this wise, Nnoli (2006) has constructively used the mining of crude oil in the Niger Delta to illustrate the dimension an average conflict takes, if it is the violent type. In the words of Nnoli (2006):

The violent conflicts that prevail in the area arise from differences of security perspectives between the local communities 


\section{of oil companies, on the one hand, and the state that negotiated the oil mining agreements, on the other hand (pp.51-52).}

Consequently, from the above stated so far, the implication is that the major source of conflicts in Nigeria's Niger Delta is environmental in nature; a difference between the people and the federal government on how lives, property and environment should be preserved, in the midst of oil prospecting activities. To the Nigerian government, oil is the national interest of the country, and it's exploitation should not be disrupted. On the other end of the divide is the oil bearing communities who completely disagree with the position taken by the government. To the communities, oil is their God-given resource, which exploitation should have direct, positive impacts on their lives and environment. They thus are asking for a bigger share of the accruing foreign exchange which oil has generated for the nation for some decades now. They argue that the revenue sharing formula should be adjusted to at least reflect the country's pre1965 principle.

The conflicting interests and positions identified above are the factors that have contributed to the level of crisis so far recorded in that part of the country. It is worth stating here that in the event that a conflict is not amicably resolved, it in most cases lead to crisis or series of crisis. At that stage, or after, the parties or and a third party could agree to find a settlement to the problem of concern. The mechanisms applied in the achievement of this envisaged pre-crisis status quo, is referred to as conflict management.

Conflict management, among others, involves conflict resolution and transformation, a process involving a long-term arrangement. In the words of Otite (1999), this arrangement must involve "institutionalized provisions and regulative procedures for dealing with conflicts whenever they occur. People must learn to manage conflicts productively; otherwise the risks to society and its environment are overwhelming" (p.11). Available literature on conflict management has observed that appropriate communication skills and channels are crucial in conflict management. Parties that are in conflict must have channels or avenues through which they could express their differences. Such an atmosphere would prove useful to the expression of one's mind, listening carefully, and in the according to Otite (1999),

expressing strong feelings appropriately, remaining rational, asking questions, maintaining a spirit of give and take, avoiding harmful statements, asking directly what is going on, telling others one's opinion, looking for flexible "shades of gray" solutions, recognizing the power of initiating a cooperative move, identifying conflict patterns, and engaging in negotiations of agreements and settlements"(p.12). 


\section{Nigerian Security Forces/Joint Task Force and the Management of internal Conflicts in the Niger Delta}

The method to be adopted in the analysis of conflict patterns by Nigerian security personnel will involve the case-study approach. This paper intends to identify a number of conflict situations that have been recorded in the country in general and the Niger Delta in particular. This analysis will expose how successful or otherwise the management of such conflicts by the military were. From Umuechem, to Odi and Gbaramatu kingdom, the military, while on national assignment to maintain the peace in these places, left behind more woes and terrorized citizenry than they met on ground.

\section{Gbaramatu kingdom}

On May 15, 2009, the Military Joint Taskforce (JTF) in the Niger Delta launched a major offensive against perceived militants inhabiting parts of Gbaramatu Kingdom in Warri South West Council of Delta State. Records indicate the fact that the JTF applied all forms of conventional warfare tactics to prosecute that attack. These included land, sea and aerial bombardment. This heavy military operation was reasoned to be necessary to enable the armed forces flush "out Niger Delta militants from the creeks of the oil-rich region" (Sunday Sun, June 7, 2009, p.8).

On the actions of the military in Gbaramatu kingdom, the editorial of Africa News Update (06:08:2009) had this to say, "President Umaru Yar'Adua's government is letting the military take the initiative in the Delta at the expense of political solution" (p.1). This source informs further that the military action in Gbaramatu proves to be the heaviest government offensive in that region in recent times. The military armory moved to that region was put at 3,000 troops, two warships, 14 boats and at least four helicopter gunships (see Africa News Update, 06.08.2009. Because of the heavy military action that ensued, Human rights groups claim, "with varying degrees of credibility that between fifty and several thousand civilians have been killed in the operation so far... The Military Joint Task Force (JTF) argued that it could no longer 'fold its hands' after weeks of attacks on soldiers, hijacking of oil vessels and kidnapping of workers around Gbaramatu. Oil production has fallen to under (sic) 1.6 million barrels per day from a peak of $2.4 \mathrm{mn}$ bpd three years ago" (Africa News Update, 06.08.2009). On the other hand, Amnesty International and others report that 20-30,000 noncombatants (civilians) caught in the cross fire, fled the area for safety near the oil centre of Warri. 
As already observed above, this operation was like a total war declared against an enemy camp, with the deployment of every kind of weapon of mass destruction from land, sea and air. This paper notes however, that this struggle has more to do with assertion for the rights of a people who have expressed fears of marginalization over the years. The presumed militant groups are not fighting a "breaking-away" war (insurrection), but trying to put pressure on the government of the day to consider the plight of the inhabitants of the Niger Delta, sending a direct consequence of oil prospecting activities in that part of the country.

Question is, have such military operations or option to conflict management solved such problems once and for all? The likely answer from available data indicates the negative. In fact, such actions have made the militants go harder and tougher on government oil facilities and officials whenever they had the opportunity. Recently (in the second week of July, 2009), the militants extended their activities to the Lagos Atlas Cove Jetty, where major oil facilities (for refined fuel and others) are located. By the time they were through with their actions, a number of facilities had been bombed, with more than five deaths recorded.

If the military option were the best solution to the lingering oil - related crisis in Nigeria, it would have sufficed to state that after the Gbaramatu military operations, the militants would down their weapons and vow never to engage in such activity any more. However, weeks after, they re-surfaced in the Lagos water/creek areas. This tends to support strongly, the thesis that there are better options to the Niger-Delta crisis than constant military bombardment and occupation. A clue from an e-mail sent by Jomo Gbomo in May, 2009 would point to one of the over stretched solutions. Said Gbomo, "our message to the Northern Sultans and Emirs is this: The period of exploiting the Niger-Delta is coming to an end. It is not the birthright of your people to rule the Federal Republic of Nigeria. The war is just beginning and by the time it ends Nigeria will practice true federalism such as fiscal federalism", (http://www.africaconfidential.com./home). This seems to be the crux of the matter.

A very significant observation about the military action recorded above is that the target-hunt (militant leader); "High Chief Government Ekpemupolo" aka Tompolo (a MEND commander) was not arrested. The implication of his escape is that like a number of military operations carried out against civilian populations in Nigeria, the Gbaramatu operation was another failed exercise.

The military after such invasions, would normally remain behind like "armies of occupation", to inflict more wound on the remaining civilians. This paper will return to further analysis of military operations in conflict-ridden sections of Nigeria, when a few other cases must have been considered. 
According to the Africa News Update (06:08:2009), "There are rumours that the army plans to establish a permanent barracks in the area, in Tompolo's father's house" (p.1).

\section{The Odi invasion}

In November 1999, it was reported that 12 police officers were killed by youths of the community. Like the Gbaramatu and ZakiBiam conflict that have been analysed above, thorough investigations (surveillance) were not conducted, with a view to fishing out the actual perpetuators of the crime. Rather, the police went on a reprisal attack, with truck loads of mobile police officers.

At the end of several days of military operations in Odi, reports had it that the entire community was destroyed, leaving out only one church and medical facility buildings standing. Civilians were killed in their numbers (more than 375 villagers). At the end, the officers remained in that community for several months. Till date however, no independent and open inquiry was made into the reported extra-judicial killings in the Odi community by the government forces.

Records made available by human rights organizations have it that many years after the Odi attack, that community is still in ruins.

An over view of the data presented above so far, strongly point to the fact that military campaigns in civil-related conflicts have caused more damages, than solve the problems that warranted the operations.

\section{Conclusion}

The fact can not be swept under the carpet that Nigeria's security forces have performed well in a number of peace-keeping operations in Africa and a number of other continents. The major problem identified though is that their performance during internal conflicts (management) in different parts of the country, especially the Niger delta region, has been largely below average. This is so because more emphasis has been placed on application of maximum force to quell civilian uprisings.

This paper ends with proffering a number of recommendations, which are likely to serve as permanent solutions to the problems that warranted this analysis.

To put paid to the lingering crisis in the Niger Delta, it is strongly recommended that caution should be applied always, before military personnel are drafted to any part of the country that has been engulfed with conflict. The soldiers could be drafted to quell uprisings, where it has been proved beyond 
reasonable doubts that insurrection (insurrection) was in the making in that part of the country. The fact is that military operations have to a large extent proved ineffective in solving civilian crisis in Nigeria. They have been rather, largely used to serve the interest of some political elites. It is politically dangerous to encourage the drafting of military personnel to settle civilian problems in a democracy. It is important to note that one of the major factors that led to the first military coup in Nigeria, and a number of others after, was the act of using military personnel to settle civilian crisis.

A permanent, formal channel for dialogue should be established among all stake holders involved in a particular crisis situation. The Niger Delta crisis for example would involve the federal government, state governments (affected) and the groups representing the people of the region. Dialogue is indeed a sine qua non for the solving of this lingering crisis. A recurring decimal in the Niger Delta question; fiscal federalism must be given adequate attention and consideration. A workable formula must be worked out on how to increase the derivation principle from the present $13 \%$.

The Nigerian armed forces, police and other security agencies should be trained and constantly refreshed on surveillance operations. This strategy will encourage a system that nips crime in the bud; than the current experience where security personnel are largely caught unawares. This is about the best among international practices on crime prevention and control.

\section{References}

Advanced English Dictionary, the ultimate reference, http://jDictionary-mobile.com

Africa News Update: the Norwegian Council for Africa, http://www.africa-confidential.com

Amnesty International Press Release, 24:10:2001. http://www.amnesty.org

Coser, L.A. The Functions of Social Conflict. Glencoe III: The Free Press e-journal@africaaction.org

Galadima, H. S. 2006. "Peace Support Operations in Africa". In Best, S.G. ed. Introduction to peace and Conflict Studies in West Africa. Ibadan: spectrum Books Limited.

http://www.africaaction.org

Nnoli, O. 2006. National Security in Africa: A Radical New perspective. Enugu: SNAAP PRESS LTD.

Otite, O. \& Albert, I.O. eds. 1999. Community Conflicts in Nigeria, Resolution and Transformation. Ibadan: spectrum Books Limited.

Sunday Sun, 07:06:2009

UNDPKO, http://www.un.org/Depts/dpko 